PALEO

Revue d'archéologie préhistorique

27 | 2016

Varia

\title{
The bison of La Grèze (Dordogne, France) under the microscope
}

Lydia Zotkina

\section{(2) OpenEdition}

Journals

Electronic version

URL: http://journals.openedition.org/paleo/3305

DOI: 10.4000/paleo.3305

ISSN: 2101-0420

Publisher

SAMRA

Printed version

Date of publication: 30 December 2016

Number of pages: $307-320$

ISSN: 1145-3370

\section{Electronic reference}

Lydia Zotkina, «The bison of La Grèze (Dordogne, France) under the microscope », PALEO [Online], 27| 2016, Online since 01 June 2018, connection on 07 July 2020. URL : http://journals.openedition.org/ paleo/3305 ; DOI : https://doi.org/10.4000/paleo.3305

This text was automatically generated on 7 July 2020 .

\section{(c) (i) (9)}

PALEO est mis à disposition selon les termes de la licence Creative Commons Attribution - Pas d'Utilisation Commerciale - Pas de Modification 4.0 International. 


\title{
The bison of La Grèze (Dordogne, France) under the microscope
}

\author{
Lydia Zotkina
}

The present study was carried out thanks to a grant from the Franco-Russian Study Center of Moscow and the support of the Artemir Associated International Laboratory.

We are thanking J.-J. Cleyet-Merle, director of the National Museum of Prehistory of Les Eyziesde-Tayac, for allowing us to work in La Grèze cave, and G. Lévy, manager of the caves of Font de-Gaume and Combarelles, for his logistical assistance.

\section{Introduction}

1 S.A. Semenov is recognized as the inventor of traceology as an archaeological discipline (СЕменов 1957; Semenov 1964), but its definition in Europe and the United States has been more restrictive than in Russia. Its field of application has long been limited to the use wear of lithic tools cutting edges, most often analyzed under the microscope at high magnification, whereas traceology was originally designed to take into account not only a great diversity of materials but also the traces of manufacturing produced by all kinds of techniques and therefore the use of different scales of observation (Longo and Skakun 2005). More generally, any archaeological object can potentially be subjected to a traceological reading since it is itself the material trace of a human action.

Moreover, the traceological approach is implicit or latent in studies that do not claim it as such or call it technological, especially in the underground environment (traces of mining, e.g. Arles et al. 2013; graphical techniques, e.g. Tosello and Fritz 2005, D'Errico et al. 2016), the validity of the approach being fundamentally dependent on the relevance of the used reference sources.

3 The study of prehistoric art offers a favorable field of application to traceology as conceived by S.A. Semenov, whether on portable support or on rock walls. In addition to the recognition of techniques, it lends itself to the study of the reconstruction of the 
chaines opératoires, that is to say, to the reconstruction of the unfolding, over time, of the actions that marked the painted, scraped, engraved, pecked or carved support.

The relative chronology of the lines constituting the figures, and that of the figures forming the compositions, are part of the register of questions that may be approached in the analysis of the representations. The main criteria considered are the chronology of the superimposition of the lines and their homogeneity, from which are deduced the order of the tracings and their belonging to the same ensemble, the technical synchrony contributing to the definition of graphic units. This approach is necessary to disentangle palimpsests (e.g. Aubry, Santos and Luis 2014), which are frequent in Paleolithic art, especially on portable supports. These, however, quickly buried because of their small dimensions, were not conducive to prolonged re-use, unlike the walls and rock surfaces potentially accessible during millennia, sometimes up to the present times. The same places could be occupied at different times of Prehistory and their graphic compositions completed or transformed by artists using rather similar codes, at our scale of perception, as in the Chauvet cave (Clottes 2010). They may also have been visited much later by individuals writing their marks for other reasons, be they graffiti marking their passage, easily distinguishable as, for example, Christian symbols superimposed on "pagan" figures (Hinout 1998) or, on the contrary, re-tracings the less obvious to discern, intended to revive the representations, as is known ethnographically (Miklashevich 2008; миклАшевич 2011), or to make them more visible during their discovery or exhibition to the public. The combinations are numerous and a stylistic analysis is not always sufficient to distinguish the original works from secondary works or later additions.

In any case, the question of time remains at the center of preoccupations, whether it concerns the relationship between two lines, between different parts of a figure, between the figures of an ensemble or between the graphic compositions of the same space (from the wall to the site). In some contexts, isotopic dating can be carried out directly on the figures when they include organic pigments, or on the carbonate deposits that seal them (e.g. Genty et al. 2011, Benson et al. 2013). But most often the dating evidence are indirect and apply to the whole of a composition when it is in contact with a stratigraphic deposit itself dated in various ways (Aubry and Sampaio 2008). Also, it is on the scale of the tracings themselves that we must look for additional clues. This is a field of investigation brilliantly illustrated by the pioneering works of D'Errico, Sacchi and Vanhaeren (2002) and Gyria and Devlet (гиРя and дэвлЕт 2010), from the signature of engraving and pecking tools, and more particularly from a distinction between lithic and metallic forms, which can sometimes be very useful in clarifying the relative chronology.

Parallel to comparison reference sources, the efficiency of the traceological analysis is based on observation and recording techniques. These have progressed considerably in recent years, thanks to 3D imaging, which has become more accessible and usable in the field at scales compatible with reading the finest traces (Plisson and Zotkina 2015). This aspect is particularly important in the case of petroglyphs because the relief of the traces or shapes makes it necessary to take into account the $3^{\text {rd }}$ dimension. Until now, the use of imprints (silicone or other) was inevitable for measurements and profiles recording (D'Errico, Sacchi and Vanhaeren 2002; гиРя and дэвлЕТ 2010), with all the risks of pollution and tearing-off this represented for the surfaces. This method, henceforth prohibited, is nowadays advantageously replaced by photogrammetry. 
7 The traceological approach developed and implemented on engraved and pecked outdoor petroglyph sites (D'Errico, Sacchi and Vanhaeren op.cit.; Gyria \& Devlet op.cit.; Zotkina 2012; ЗОТКИНА 2013; ЧЕРЕМИСИн et al. 2013; Zotkina et al. 2014; Avrillaud 2015; Plisson and Zotkina 2015), had not yet demonstrated its utility in underground environments where painted figures concentrate most of the analyzes. As a demonstration, we have applied it to the question of the re-tracing of figures, starting from the preliminary example of the bison of La Grèze cave.

\section{Case study}

8 The cave-shelter of La Grèze is a small cavity in the Grande Beune valley, below the vicinal road connecting the RD 48, in the municipality of Marquay in the Dordogne (Patriarch 24255 0003). It is known for its $60 \mathrm{~cm}$ by $40 \mathrm{~cm}$ bison figure (fig. 1), well preserved due to its position in a concave recess of the wall protecting it from erosion, unlike other animal representations of which only the lower parts remain.

Figure 1 - Global 3D view of the bison of La Grèze cave, made by photogrammetry. Orthographic projection, with and without colored texture. Very dense points clouds (47 million vertices).

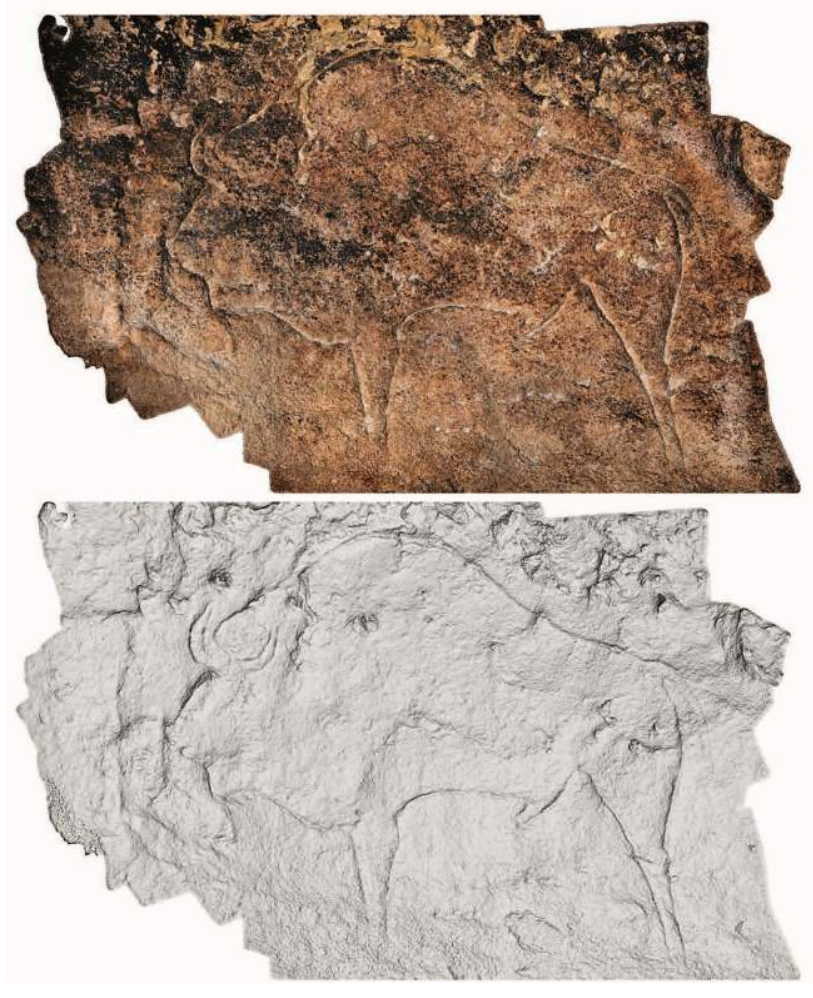

(Photo H. Plisson)

9 The cave and its engravings have been studied for more than a century, from 1904 (Capitan, Breuil and Ampoulange 1904a, 1904b) and several researchers succeeded one another (Ampoulange and Pintaud 1955; Aujoulat 1984; Breuil 1952; Cretin 2015; Delluc and Delluc 1991, 1992; Delluc and Bouvier 1984; Jaubert 2008; Peyrony 1949; Roussot 1965; Sonneville-Bordes 1960, 1965; Vidal 1967). 
Thanks to modern techniques we can now extend their work and answer some of their questions.

\section{1 - Has the bison figure been over-engraved?}

11 The light color of the bison's tracing attracts attention, and it was assumed that this fact could be explained by a re-tracing of the figure: "It is not impossible that the lines were recently over-engraved with a sharp tool, as the limestone is much lighter at the bottom of the lines than on their sides" (Delluc and Delluc 1991 - p.238); "... incidentally, the famous bison shows some traces of molding and perhaps its contour has been discreetly overengraved" (Delluc and Delluc 1991- p. 245).

\section{2 - Technique: pecking or deep engraving?}

In all the publications dedicated to La Grèze, the researchers mention the figuration of the bison as engraved (Peyrony 1949; Breuil 1952; Aujoulat 1984; Delluc and Delluc 1991). "The engraving is done by deep lines with angular section whose bottom is more or less blunt. The edges are often rounded, but this modeling of the inner edge may be related more to erosion than to human origin "(Delluc and Delluc 1991-p. 238).

But Rigaud (1984 - p. 278) mentions another technique that may also have been used: "The other lines are several fine lines with angular sections, vigorous lines obtained by pecking, and some broad lines, probable remains of vigorously engraved lines."

14 The technique of pecking can be considered as one of the explanations for the irregularity of the bison tracings.

\section{3 - Does the alteration of the support modify the engravings?}

15 The first thing to consider when dealing with technical traces in rock art, and more generally in traceology, is the influence of the natural alteration of surfaces on the lines and on the features that are a priori seen as being typical, that is to say resembling tool marks (Kervazo et al. 2010). Without understanding the effects and mechanisms of the alteration, the risk of drawing false conclusions is not negligible.

16 That is why this question must come first in the context of such research.

\section{Techniques, methods and equipment}

17 This research focuses on traceological aspects. It changes the scale of observations and allows a deeper understanding of the mechanisms of transformation of the reliefs of the rock surface.

Our observations were made with a binocular microscospe WILD M1A (x7, x14). The working distance of this microscope (about twenty centimeters) is high and allows avoiding accidental contact with the examined surface. Its lightness makes it possible to work without a tripod (fig. 2). 
Figure 2 - In situ examination system.

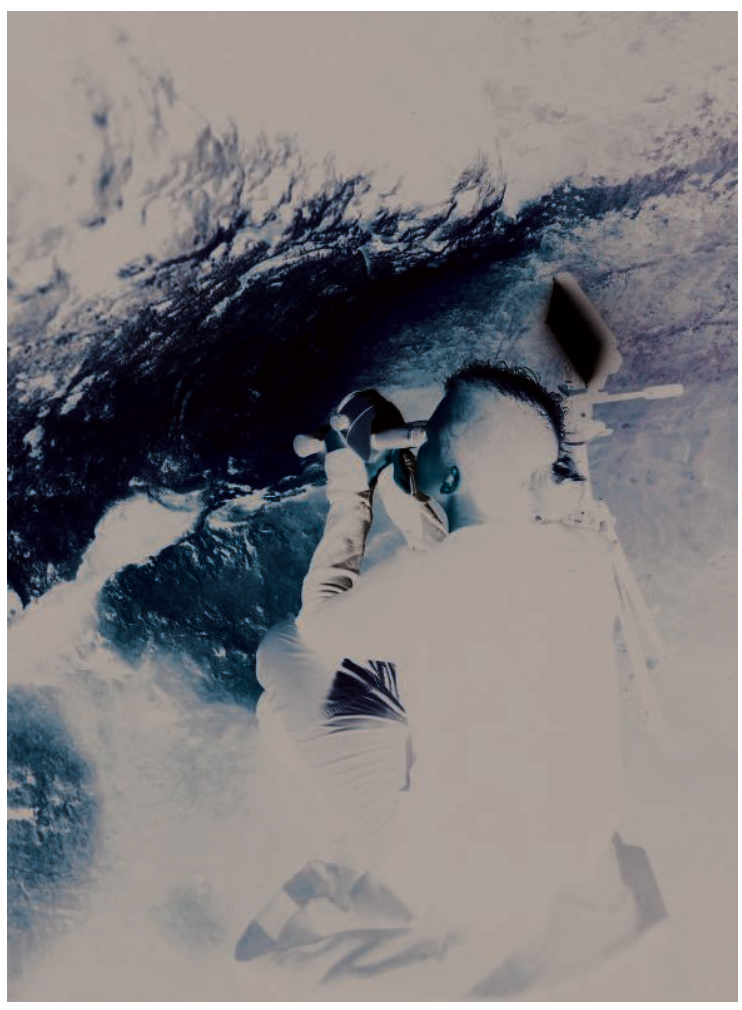

(Photo H. Plisson)

19 For the recording and comparison of reliefs we used photogrammetry (Plets et al. 2012; Robert et al. 2012; Belarbi et al. 2012; Cassen et al. 2012; Plisson 2015). Photographs were taken using a Nikon 750D camera (35.9 x $24 \mathrm{~mm}$ sensor, 24.93 million pixel resolution), equipped with an AF-S Micro NIKKOR 60mm f / 2.8G lens and a ring flash. The models are generated and processed with the Agisoft Photoscan, MeshLab and GeoMagic software, from which cross-sections of the tracings are extracted.

We have also made macros showing the characteristic details of the figure with a Canon $1000 \mathrm{D}$ case $22 \times 15 \mathrm{~mm}$ format with a Canon EF-S $60 \mathrm{~mm} \mathrm{f} / 2.8$ Macro USM lens and extension rings attached to a rack rail and a robust tripod. The photographic sequences were conducted from a computer and then compiled with the Helicon Focus software to obtain high-resolution, hyper-focus views.

During the observations and recordings, we have used Aurora Max 5600 LEDs lighting system whose luminous intensity and color temperature could be adjusted.

The experimental references for comparison are those developed in the author's recent thesis (Zotkina 2013), established on different terrains, and enriched by archaeological and ethnographic examples related to different techniques (Plisson and Zotkina 2015), with lithic and metal tools. The observations carried out at La Grèze were supplemented by tests (fig. 7) on small blocks fallen outside at the foot of the shelter.

But we must consider that the means used here are not always possible in the configuration of decorated caves (difficulties of lighting, difficulties in approaching the panels, fineness of certain engravings, extent of decorated surfaces, etc.). 


\section{Grooving, pecking or alteration of the surface?} wall, are very irregular and sometimes very deep. Some surface portions of the two figures are very alveolar. This makes it possible to speculate that these lines would have been done by the pecking technique. B. and G. Delluc indicate a fairly visible variation in the depth (between 2 and $7 \mathrm{~mm}$ ) and the width (between 3 and $12 \mathrm{~mm}$ ) of the lines of the bison (Delluc and Delluc 1991 - p. 238). The tracings are sometimes described as having a "recticurvilinear" section (op. cit., fig. 168). The technique of photogrammetry makes it possible to reproduce precisely their morphology (Plisson and Zotkina 2015). On our 3D models we can see sections that cannot be described as typical for engraving lines (D'Errico, Sacchi and Vanhaeren 2002), which usually rather have a regular profile more or less in $\mathrm{V}$ (fig. $3 \mathrm{a}$-g) .

Figure 3 - Irregular outline of the bison hump: global view of the bison with the area under focus; a outline of the hump with very irregular edges; $b, c-3 D$ model of the area; $d$ - macrophotography of the hump outline (lower side) and of the natural alteration of the wall (upper side); e - cross sections of both zones (natural alteration and tracing); $f, g$ - macrophotographic details of the hump outline.

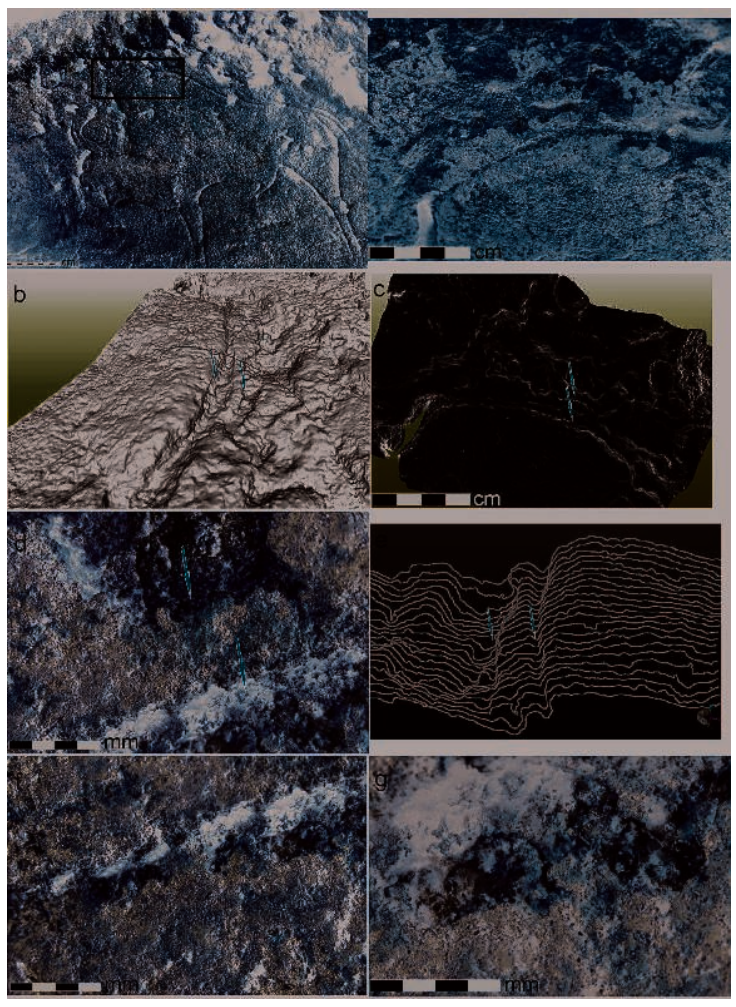

(Photo L. Zotkina)

It is evident, however, that the support is fragile and quite altered, as already mentioned by Delluc (1991: 235).

During our observations with the binocular microscope we observed the following characteristics:

The conservation of tool marks in the representations of other caves in the region (e.g. Combarelles I and II, Font-de-Gaume) can be much better than in La Grèze; there are signatures much more visible and revealing. Indeed, on the edge of the broad and deep 
main groove of the bison, we have no finer traces that account for the specificities of the active part of the tool, nor a parasitic tracing revealing deviation in gesture. The high level of alteration does not allow to go beyond the survey of the profiles of the groove. This comparison leads us to believe that the state of preservation not only of the support itself but also of the prehistoric tracings on the walls of La Grèze is not conducive to a thorough traceological research.

The comparison of some tracings of the bison (fig. 3, a, f) with the naturally altered parts that do not have an engraved line morphology but that resembles them at the level of the contour (fig. 3, d, e) shows similarities suggesting that areas considered to be pecked would in fact be altered (fig. 3).

This is why we suppose that we are not observing tool marks but forms produced by alteration (fig. 3, 4).

Figure 4 - Engraving and natural or accidental traces: a, b - samples of a natural or accidental linear mark on the flank of the bison; $c, d, e, f$ - zones of back outline of the bison with regular edges and $V$ profile; $g, h$ - 3D models of the regular outline of the bison hump.

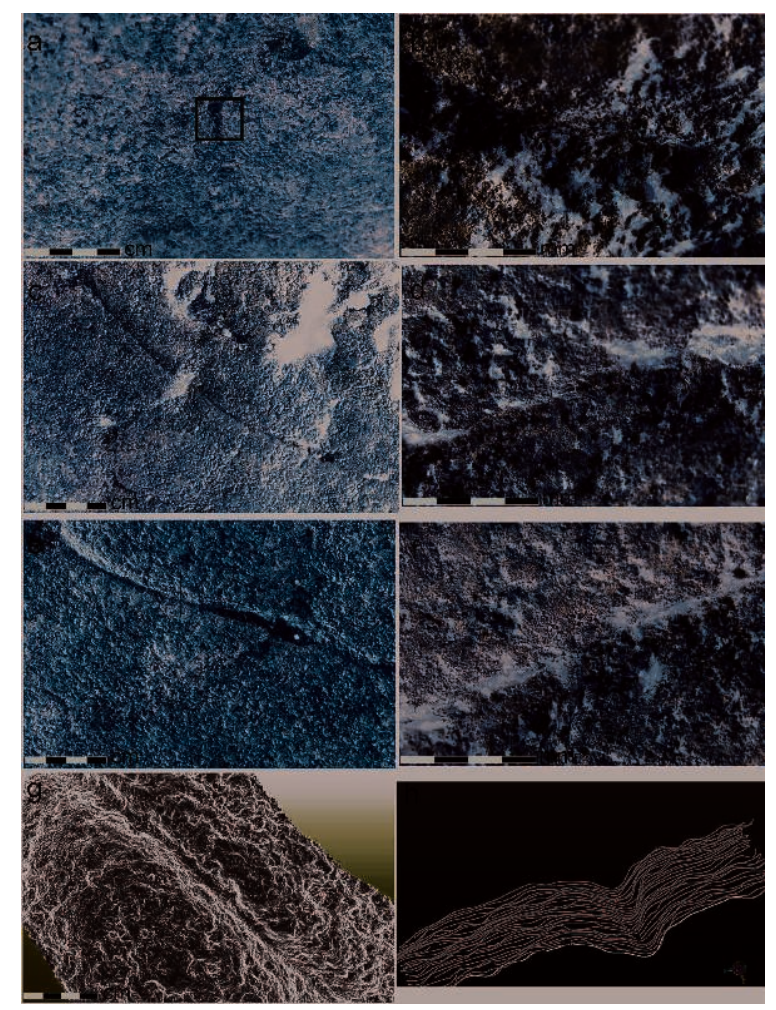

(Photo L. Zotkina)

We are fortunate to have some more striking features, like those on the back of the bison (fig. $4 \mathrm{c}-\mathrm{h}$ ): the line is rather narrow and the edges almost regular, which cannot be obtained by pecking. We also notice a line at the bottom of the tracing that is not really an imprint of the active part, because the surface is still quite altered, but that nevertheless shows the general relief of the line. This line evokes a gesture rather resembling grooving, and therefore deep engraving. We are in the part of the figuration where the surface is rather better preserved compared to the other zones. Above all, it seems to us that the gesture has not been very vigorous. 
31 horns is important to describe: it is visible (fig. 5), when the lines change orientation in a rather sudden manner, certainly where the material has resisted the tool during the tracing. Indeed, when crossing harder parts of the material the tool has deviated. This is very typical of the technique of engraving, because the tool follows the surface while remaining almost constantly in contact, and is guided by the structure of this material, which is not at all the case with pecking.

Figure 5 - Bison horns: engraved outlines (red lines underline the parts with a higher resistance to the tool trajectory).

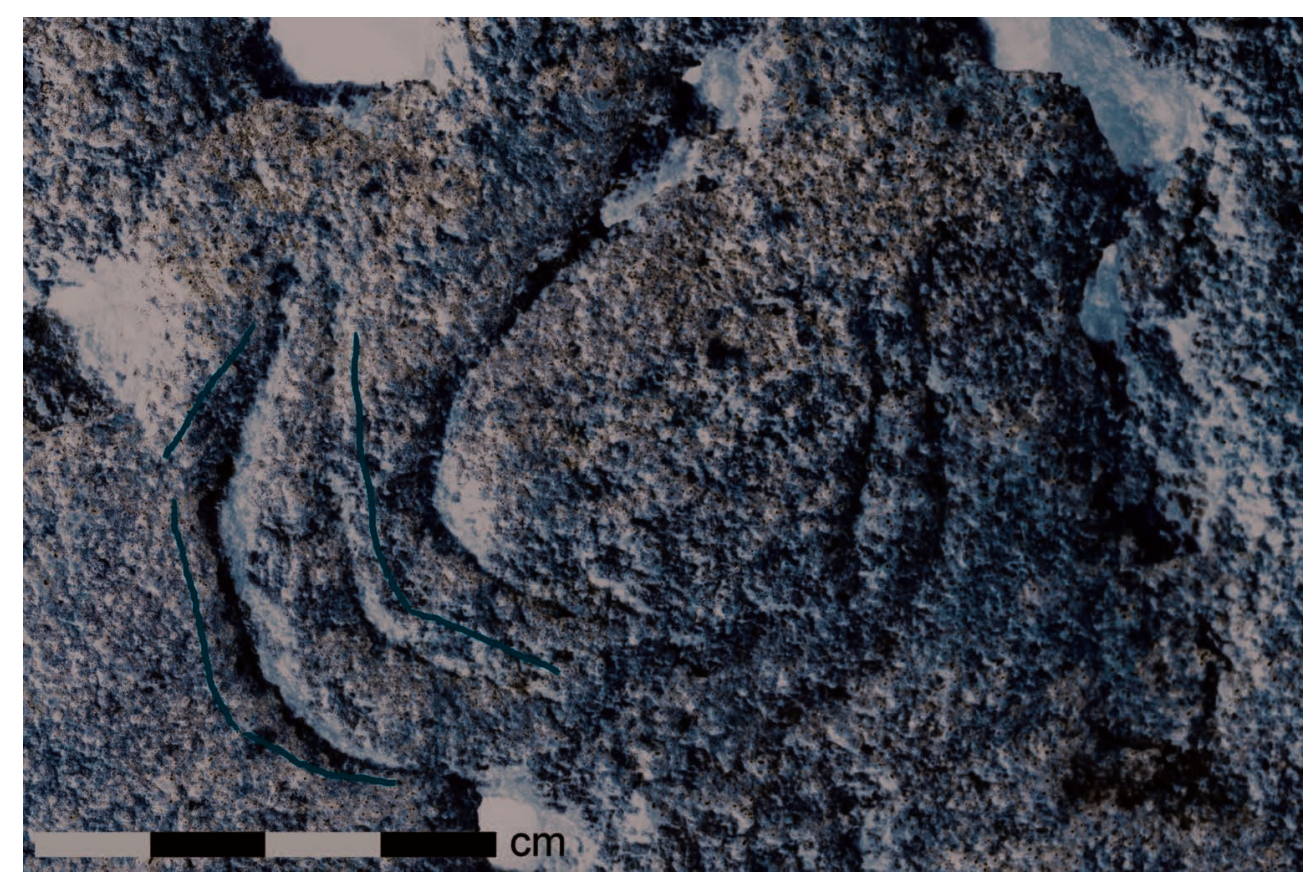

(Photo L. Zotkina)

A further argument is the damaging of the representation of the mammoth (fig. 6) located about fifty centimeters to the left, on the same wall. We observe the consequences of the desquamation that almost destroyed the figure (fig. $6, \mathrm{a}, \mathrm{b}$ ). There are nevertheless some preserved traces, for example an extremely narrow and deep line with regular edges, which is at the level of the leg (fig. 6c). This allows us to say that the alteration of the surface has widened the lines and modified their configuration. 
Figure 6 - Engraved mammoth: a - shoulder of the mammoth, very altered and irregular surface; $b$ photographic view and 3D model of the large altered outline of the body; $c$ - photographic view and 3D model of a fine outline covered by a rough concretion.

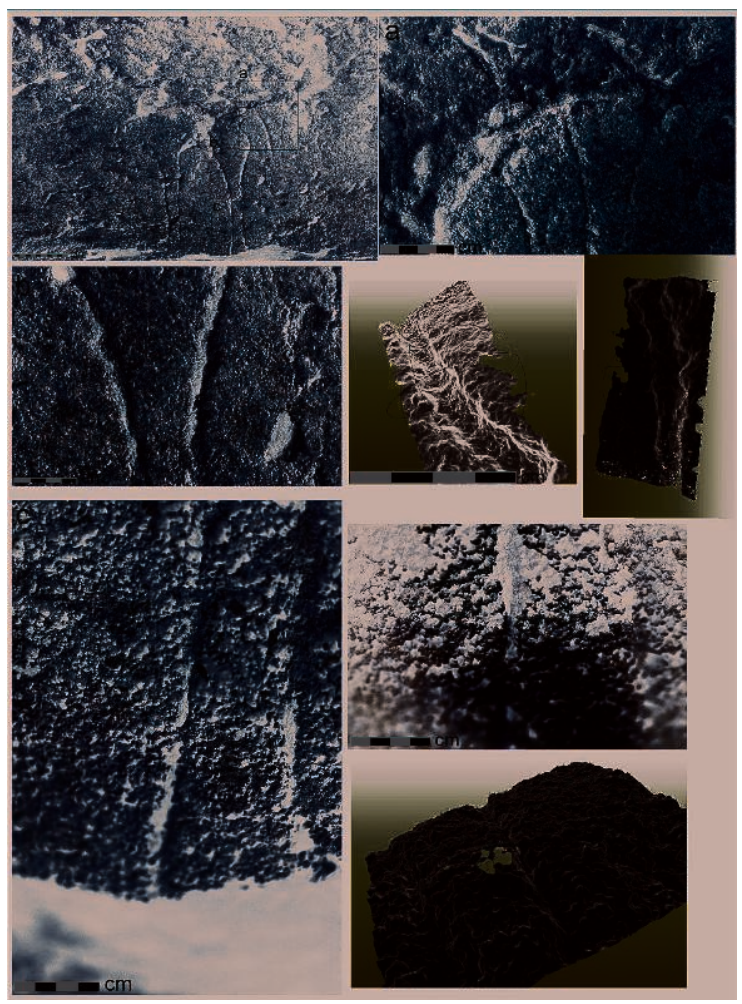

(Photo L. Zotkina)

33 We therefore come to the conclusion that the representation of the bison was carried out by the technique of deep engraving, which may be described as grooving, but that the evolution of the wall has, in some places, given the tracing a pecked appearance .

\section{Experimental verification}

Six geological facies were identified in the cave (Le Filiâtre in Cretin et al., 2015 -p.50, fig $1 / 23$ ). Most of the figures, at least the most famous one, are engraved in the $D$ facies, "pseudo-oolitic white limestone." It is a fairly homogeneous and tender material, easy to work by the engraving technique. For our experiments, we took small blocks from the same facies (fig. 7). We have tested a grooving method capable of producing a deep furrow like that of the silhouette of the bison, as it can be observed in the least altered portions of the tracing. We used a local flint flake, on the raw surface in the surrounding humidity of a spring undergrowth, but without the addition of water or other components. 
Figure 7 - Experimental engraving: $a, b$ - 3D model of deep engraved outline.

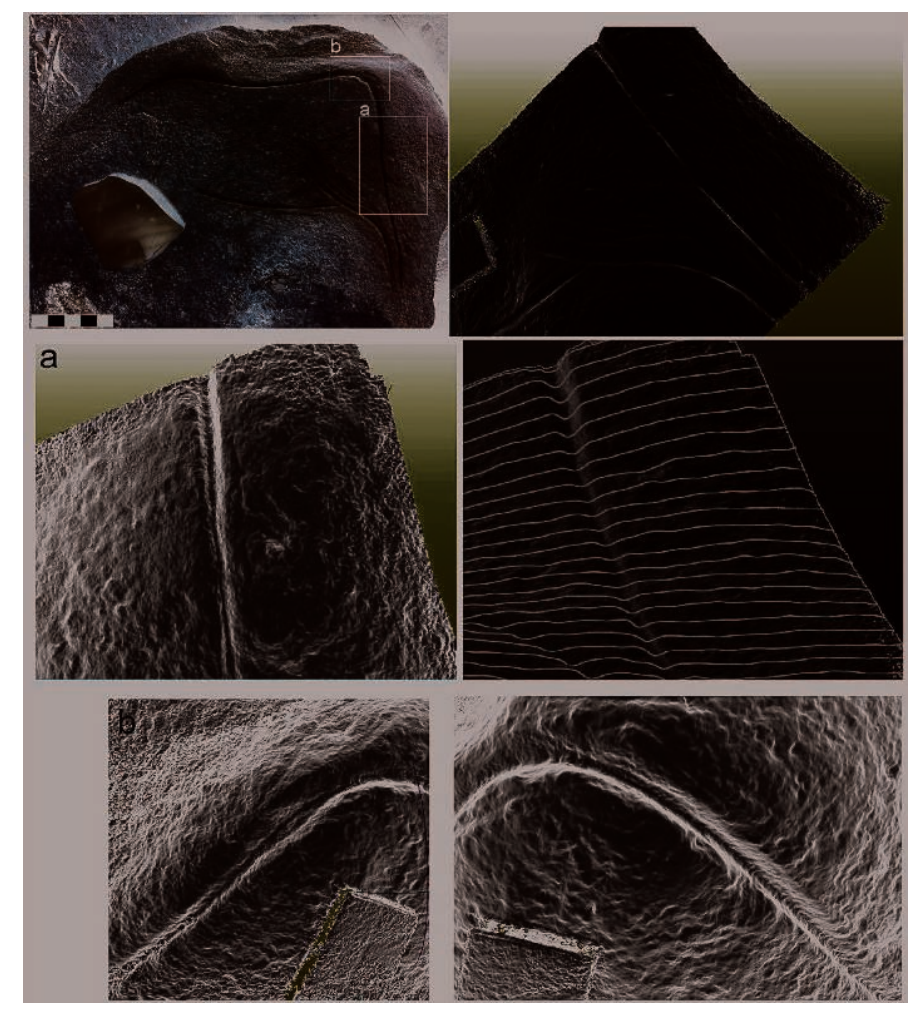

(Photo L. Zotkina)

35 A deep groove was obtained by combining two gestures: first a vigorous gesture by repeating the movement 4 to 5 times in one direction, until a fairly marked groove makes it possible to guide the active end of the tool, then the deepening by a back and forth movement. When the tracing becomes deep enough, the tool then begins to smooth out the edges of a groove, which gradually becomes rounded (fig. 7, a, b). This corresponds well to the sections of the bison tracing at the level of the back (fig. 4c, f) where we recognize the characteristic traces of the grooving. The contour of its head is more drawn out, which involved tilting the tool to reduce the outer edge of the groove.

\section{Lighter lines}

As mentioned above, researchers have raised the question of the renewal of the bison tracing (Delluc and Delluc 1991 - p. 238, 245). In our observations, we identified only two zones, reduced in size, where the bottom of the line is dark, that is to say the color of the wall: these two zones are located at the level of the tail and back. All the other parts of the engraving are light.

To determine if the figure was over-engraved in contemporary times, two aspects are to be considered. The first relates to the natural alteration of the area concerned and its relation to the tracing, and the second to the marks that would be specific to a modern tool.

As we have remarked, with the alteration, the surface becomes very irregular and the edges of the natural concavities are rough but these areas are quite light. If we compare them to the profiles of the areas of the bison figure that we consider to be very altered, 
and to those that show representative features of deep engraving technique, we see that the former are much closer to the shapes of degradation than the latter (fig. 3, fig. $4 \mathrm{a}, \mathrm{b}$, fig. $6 \mathrm{a}, \mathrm{b}$ ). In places it is seen that the dark and narrow groove is transformed very gradually into a wider groove, much less regular and lighter, which we consider to be the consequence of the alteration (fig.4c, e).

Our observations with a binocular microscope showed no sign of a modern tool in the bison tracing, nor in the mammoth's, which should be the case if the figures had been recently re-traced. We have examples of contemporary traces made during the excavation of the cave. On the one of figure 8 , referenced as such by the managers of the cave, we can clearly see the marks of the tool that attacked the material: the bottom of the line was compacted and somewhat smoothed (fig. 8), and especially fine lines, which underline the movement, are clearly visible (fig. 8). These traces are also on the wall opposite to that of the bison but whose surface state is very similar. They can therefore be taken into consideration when comparing technical traces and taphonomic traces and, subsequently, be included in the argumentation: nothing supports the hypothesis of a modern re-tracing of the figures of the bison and the mammoth. The widening of the tracing and its irregularities are only due to the natural alteration of the wall.

Figure 8 - Recent marks from the beginning of the $20^{\text {th }}$ century: $a, b$ - quite visible tools marks; $c$ $3 \mathrm{D}$ model of one of these modern traces with tool marks on the groove edges.

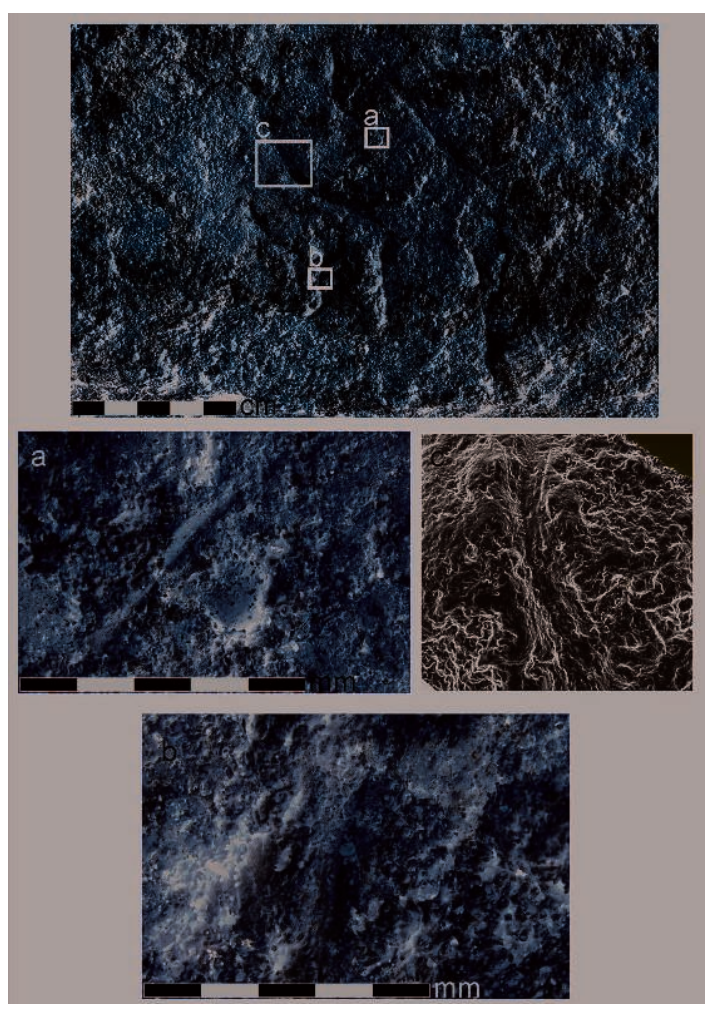

(Photo L. Zotkina)

The argument that the light bottom of some portions of the tracing would show a recent re-tracing is ultimately not so decisive, as this is one of the consequences of the alteration. Several zones of natural desquamation are equally as light (fig. 3, fig. 4, a, b, fig $6, a, b)$. The phenomenon affects the degraded areas of the bison as well as the 
mammoth. It is active both on a macroscopic scale, with a very perceptible effect, and on a microscopic scale where a micro-desquamation, albeit less blatant, also inexorably alters the surface and thus the millenary patina that had darkened the tracings. However, the method applied here does not allow us to say at what period this alteration occurred or what its intensity was.

We can therefore conclude that the present appearance of the figuration of the bison of La Grèze owes nothing to a recent intervention.

\section{Conclusion}

42 If the silhouette of the freshly engraved La Grèze bison appeared at the time, in all probability, lighter than the wall, the perception we have of it today is not due to the freshness of the line but to an alteration of uneven intensity, having in some places over-dug the tracing, whitening it again giving it the appearance of re-tracing with a different technique from that used by the Paleolithic artist. A fine analysis of this tracing, using a stereoscopic magnifying glass, and two- and three-dimensional detail recordings, reveal only two categories of features: some relating to deep, old engraving and others to the natural degradation of the wall. No feature can be related to pecking or to any more recent intervention on the figure itself, whereas the wall shows, elsewhere, marks of tools probably dating from the initial excavations in the cavity.

The traceological approach is an integral part of the study of painted prehistoric representations. The problematic of modern re-tracings, or largely subsequent to their initial making, deals here with engraved, carved and pecked forms; it opens up an additional field of expertise to traceology, which we have illustrated with the representation of the bison of La Grèze cave.

\section{BIBLIOGRAPHY}

\section{References}

AMPOULANGE M., PINTAUD R.C. 1955 - Une nouvelle gravure de la grotte de La Grèze, Bulletin de la Société préhistorique française, 53, p. 249-250

ARLES A., CLERC P., SARAH G., TÉREYGEOL F., BONNAMOUR G., HECKES J. et KLEIN A. 2013 - 3D reconstruction and modeling of subterranean landscapes in collaborative mining archaeology projects: techniques, applications and experiences. In: XXIV International CIPA Symposium, 2 - 6 September 2013, Strasbourg, France. / vol XL-5/W2. 2013 (International Archives of the Photogrammetry, Remote Sensing and Spatial Information Sciences).p. 61-66.

AUBRY T. et SAMPAIO J. D. 2008 - Fariseu: new chronological evidence for open-air Palaeolithic art in the Côa valley (Portugal). Antiquity, vol 82, n³16. http://antiquity.ac.uk/ProjGall/ aubry316/ 
AUBRY T, SANTOS A. T., LUIS L. 2014 - Stratigraphies du panneau 1 de Fariseu :analyse structurelle d'un système graphiquepaléolithique à l'air librede la vallée du Côa (Portugal), inPaillet P. (dir.), Les arts de la Préhistoire : micro-analyses, mises en contextes et conservation,Actes du colloque « Micro-analyses et datations de l'art préhistorique dans son contexte archéologique »,MADAPCA - Paris, 16-18 novembre 2011, Paleo, numéro spécial, p. 259-270

AUJOULAT N. 1984 - Grotte de La Grèze, L'art des cavernes. Atlas des grottes ornées paléolithiques françaises. Ministère de la Culture, Imprimerie Nationale, Paris, p. 164-166, 4 fig.

AVRILLAUD C. 2015 - Les saignées "naviformes" dans l'art rupestre postglaciaire : caractérisation morphologique et techno-tracéologique. Master 2 Anthropologie biologique - Préhistoire, Bordeaux : Université de Bordeaux, $69 \mathrm{p}$.

BELARBI M., RAYMOND P., SAULIÈRE N., TOUQUET R. 2012 - Acquisition 3D par photogrammétrie et illustration archéologique. JIAP. Livret des communications. Paris, L'Institut d'Art et d'Archéologie, p. 3.

BENSON L. V., HATTORI E. M., SOUTHON J. et ALECK B. 2013 - Dating North America's oldest petroglyphs, Winnemucca Lake subbasin, Nevada. Journal of Archaeological Science, 2013, vol 40, $\mathrm{n}^{\circ} 12$, p. 4466-4476.

BREUIL H. 1952 - Quatre cents siècles d'art pariétal. Les cavernes ornées de l'âge du renne. Montignac, Centre d'Études et de documentation préhistoriques, p. 286-287.

CASSEN S., LESCOP L., CRIMAUD V., SUNER B. 2012 - Bienfaits et limites d'un enregistrement lasergrammétrique dans la tombe à couloir de Gavrinis (Morbihan, France). JIAP. Livret des communications. Paris, L'Institut d'Art et d'Archéologie, p. 4.

CAPITAN L. BREUIL H., AMPOULANGE M. 1904a - Une nouvelle grotte préhistorique à parois gravées : la grotte de La Grèze (Dordogne), Comptes-rendus de l'Académie des Inscriptions et BellesLettres, $48^{\text {è }}$ année, $\mathrm{n}^{\circ}$ 5, p. 487-495.

CAPITAN L., BREUIL H., AMPOULANGE M. 1904b - Nouveaux détails sur la grotte à parois gravées de La Grèze, Comptes-rendus des séances de l'Académie des Inscriptions et Belles-Lettres, 48ème année, $\mathrm{n}^{\circ} 5$, p. 487-495.

CLOTTES J. 2010 - La grotte Chauvet : l'art d'origine. Seuil, 226 p.

CRETIN C., (dir.), avec la collab. de Armand D., Boche E., Bruxelles L., Cahoreau N., Chancerel A., Deneuve E., Genty D., Hoerlé S., Konik S., Le Fillâtre V., Lesvignes E., Madelaine S., Man-Estier E., Mangier E., Mensan R., Morala A., Muth X., Paillet P., Petrognani S., Plisson H., Robert É., Sisk M.L., Archambeau C., Bureau P., Couture C., Henriette C., Jugie Ph., Portais J.-C., Vanzo J.-P., Veyret M. 2015 - PCR Archéologie des sites ornés de Dordogne : cadre conceptuel, potentiels, réalité et opérations associées. Rapport 2014. Opération archéologique ${ }^{\circ}$ 2014-64. Bordeaux : Service régional de l'archéologie, $433 \mathrm{p}$.

2015 - Archéologie des sites ornés de Dordogne : cadre conceptuel, potentiels et réalité, rapport de Programme collectif de recherche du Ministère de la Culture et Communication, Opération archéologique n²014-64, 229 p.

DELLUC B. et DELLUC G. 1991 - L'art pariétal archaïque en Aquitaine, XXVIIIème supplément à Gallia Préhistoire, CNRS Ed., Paris, 390 p.

DELLUC B. et DELLUC G. 1992 - Grèze (La), La naissance de l'art en Europe, Union Latine, Paris, p. 281-282.

DELLUC B. et G., BOUVIER J.-M. 1984 - Deux nouvelles gravures dans la grotte de La Grèze, Bulletin de la SHAP, 111, p. 253-259. 
D'ERRICO F., DAYET BOUILLOT L., GARCIA-DIEZ M., PITARCH MARTI A., GARRIDO PIMENTEL D. et ZILHÃO J. 2016 - The technology of the earliest European cave paintings: El Castillo Cave, Spain. Journal of Archaeological Science, 2016, vol 70, nJune, p.48-65.

D'ERRICO F., SACCHI D. et VANHAEREN M. 2002 - L'analyse technique de l'art gravé de FornolsHaut, Campôme, France. Implications dans la datation des représentations de style paléolithique à l'air libre. In : Sacchi D. dir, L'art paléolithique à l'air libre : le paysage modifié par l'image, TautavelCampôme, 7-9 octobre 1999.Carcassonne, Gaep \& Géopré, p. 75-86.

GENTY D., KONIK S., VALLADAS H., BLAMART D., HELLSTROM J., TOUMA M., MOREAU C., DUMOULIN J-P., NOUET J., DAUPHIN Y.,WEIL R. 2011 - Dating the Lascaux cave gours formation. Radiocarbon, Volume 53, $\mathrm{n}^{\circ}$ 3, p 479-500.

HINOUT J. 1998 - Les pétroglyphes mésolithiques des massifs gréseux du Bassin parisien. Revue archéologique de Picardie, vol 3, n¹, p. 31-52.

JAUBERT J. 2008 - L'« art » pariétal gravettien en France : éléments pour un bilan chronologique, Le Gravettien : entités régionales d'une paléoculture européenne, Table ronde - Les Eyzies Juillet 2004, Les Eyzies-de-Tayac, Paleo, 20, p. 439-474, 27 fig., 2 tabl.

KERVAZO B., FERUGLIO V., BAFFIER D., DEBARD É., FERRIER C., PERROUX A.-S., AUJOULAT N., DELANNOY J.-J. et PERRETTE Y. 2010 - Paroi et art pariétal : approche taphonomique. L'exemple de la grotte Chauvet-Pont d'Arc (Ardèche), Paleo Supplément n 4 - septembre 2010, Mise en commun des approches en taphonomie - IUSPP - Lisbonne - 2006, p. 43-52

LONGO L. et SKAKUN N. 2005 - The roots of use-wear analysis: selected papers of S.A. Semenov.

Memorie del Museo Civico di Storia Naturale di Verona (2 serie). Sezione Scienze Dell'Uomo, 7. Verona: Museo Civico di Storia Naturale - Verona, $141 \mathrm{p}$.

MIKLASHEVICH E. 2008 - Rock Art Research in Siberia and Central Asia, 2000-2004, Rock Art Studies. News of the World, III, Oxbow Books, Oxford, UK, pp. 138-179.

PEYRONY D. 1949 - La grotte de La Grèze, commune de Marquay, Bull. Soc. Hist. Arch. Périgord, 76, pp. 53-58, 1 fig.

PLETS G., GHEYLE W., VERHOEVEN G., DE REU J., BOURGEOIS J., VERHEGGE J., STICHELBAUT B. 2012 - Three-dimensional recording of archaeological remains in the Atlai Mountains. Antiquity Publications, n $^{\circ 6}$. p. 884-897.

PLISSON H. 2015 - Digital photography and traceology: from 2D to 3D. Traces in the history. Dedicated to 75 anniversary of Viacheslav E. Shchelinsky. / dir par Lozovskaya O.V., Lozovski V.M. et Girya E. Yu. Saint Petersbourg : IIMKRAN, p.272.

PLISSON H. et ZOTKINA L. V. 2015 - From 2D to 3D at macro- and microscopic scale in rock art studies. Digital Applications in Archaeology and Cultural Heritage, vol 2, n²-3, p. 102-119.

RIGAUD J.-P. 1984 - Grotte de La Grèze, Gallia Préhistoire, Informations archéologiques : circonscription d'Aquitaine, t. 27, fasc. 2, p. 278.

ROBERT E., EGELS Y., BOCHE E., VIGEARS D., VIALOU D. 2012 - La photogrammétrie en grotte ornée : application pour l'étude et la contextualisation de l'art préhistorique dans les grottes Blanchard (Indre) et Rouffignac (Dordogne). JIAP. Livret des communications. Paris, L'Institut d'Art et d'Archéologie, p. 26

ROUSSOT A. 1965 - Les découvertes d'art pariétal en Périgord, Centenaire de la Préhistoire en Périgord (1864-1964), supplément au Bulletin de la SHAP, Périgueux, t. 91, p. 115. 
SEMENOV S. A. 1964. Prehistoric technology; an experimental study of the oldest tools and artefacts from traces of manufacture and wear. London: Cory, Adams \& Mackay, 1964, 211 p.

SONNEVILLE-BORDES D. (de) 1960 - Le Paléolithique supérieur en Périgord, Thèse de doctorat, Delmas Imp., Périgueux, p. 321, 1 fig. et pp. 427-428, 1 fig.

SONNEVILLE-BORDES D. (de) 1965 - Les industries des abris et grottes ornées du Périgord. Centenaire de la Préhistoire en Périgord, 1864-1964, nº spécial du Bulletin de la Société Historique et Archéologique du Périgord, p. 176.

TOSELLOG. et FRITZ C. 2005 - Les dessins noirs de la grotte Chauvet-Pont d'Arc : essai sur leur originalité dans le site et leur place dans l'art aurignacien. Bulletin de la Société Préhistorique Française, vol 102, n¹, p. 159-171

VIDAL P. 1967 - Grottes et abris ornés de la vallée de la Vézère (Dordogne), Spelunca Bulletin, 3, p. 194-201, 3 fig.

ZOTKINA L. V. 2012 - Études technologiques des pétroglyphes de Sibérie (site de Shalobolino, région de Krasnoyarsk). In : J. Clottes dir, L'art pléistocène dans le monde. Actes du Congrès IFRAO. Tarascon-sur-Ariège, septembre 2010. Société Préhistorique Ariège-Pyrénées, p. 189-190.

ZOTKINA L. V., TEKHTEREKOV A. S., KHAREVITCH V. M. et Plisson H. 2014 - An Experimental Study of Percussion Technologies in the Minusinsk Basin: Percussion and Tool Types. Archaeology, Ethnology and Anthropology of Eurasia, vol 42, n¹, p. 55-65.

ГИРЯЕ.Ю., ДЭВЛЕТЕ.Г. 2010 - Quelques résultats de la recherche méthodologique dans l'étude de la technique de piquetage en art rupestre (НЕКОТОРЫЕРЕЗУЛЬТАТЫРАЗРАБОТКИМЕТОДИКИИЗУЧЕНИЯТЕХНИКИВЫПОЛНЕНИЯПЕТРОГЛИФОВПИКЕТАЖЕМ). УРАЛЬСКИЙИСТОРИЧЕСКИЙВЕСТНИК, $\mathrm{n}^{\circ} 1$ (26), ЕКАТЕРИНБУРГ, p. 107-118.

миклАшевичЕ. А. 2011 - À l'étude de la technique d'exécution des représentations de Tomskayapissanitsa (КИЗУЧЕНИЮТЕХНИКИНАНЕСЕНИЯИЗОБРАЖЕНИЙТОМСКОЙПИСАНИЦЫ).ИСТОРИКО-КУЛЬТУРНОЕ НАСЛЕДИЕ КУЗБАССА (АКТУАЛЬНЫЕ ПРОБЛЕМЫ ИЗУЧЕНИЯ И ОХРАНЫ ПАМЯТНИКОВ АРХЕОЛОГИИ), ІІІ, КУЗБАССИЗДАТ, КЕМЕРОВО, РОССИЯ, р. 132-155.

СЕМЕНОВ С.А.1957 - Technologie préhistorique (ПЕРВОБЫТНАЯ ТЕХНИКА). МАТЕРИАЛЫ И ИССЛЕДОВАНИЯ ПО АРХЕОЛОГИИ СССР, 54. МОСКВА, ЛЕНИНГРАД: АКАДЕМИЯ НАУК СССР, 1957, 240p.

ЗОткина л.В. 2013 - Pétroglyphes piquetés du bassin de Minoussinsk (aux matérieux de la recherche techno-tracéologique) (ПЕТРОГЛИФЫ ХАКАССКО-МИНУСИНСКОЙ КОТЛОВИНЫ, ВЫПОЛНЕННЫЕ В ТЕХНИКЕ ПИКЕТАЖА (ПО ДАННЫМ ТЕХНОЛОГО-ТРАСОЛОГИЧЕСКОГО ИССЛЕДОВАНИЯ)). КАНДИДАТСКАЯ ДИССЕРТАЦИЯ. АРХЕОЛОГИЯ, НОВОСИБИРСК: НОВОСИБИРСКИЙ ГОСУДАРСТВЕННЫЙ УНИВЕРСИТЕТ, $304 \mathrm{p}$.

ЧЕРЕМИСИН Д.В., ЗОТКИНА Л.В., МИКЛАШЕВИЧ Е.А., ЛБОВА Л.В., ЖЕНЕСТ Ж.-М., ПЛИССОН Ю.,КРЕТАНК. 2013 - Étude technologique de l'art rupestre des monts d'Altaï en 2013 (ИССЛЕДОВАНИЕ ТЕХНОЛОГИЧЕСКИХ ОСОБЕННОСТЕЙ НАСКАЛЬНЫХ ИЗОБРАЖЕНИЙ ГОРНОГО АЛТАЯ В 2013 ГОДУ). МАТЕРИАЛЫ ИТОГОВОЙ СЕССИИ ИНСТИТУТА АРХЕОЛОГИИ И ЭТНОГРАФИИ СО РАН, volXIX, p.362-368. 


\section{ABSTRACTS}

The scope of traceology, as defined by S.A.Semenov who founded the discipline, was broad, but in half a century most of the studies have focused on the use wear of lithic tools. Nonetheless, some pioneer works show that the analysis of tool marks can provide useful data to rock art studies and helps to address questions about the techniques, the "chaîne opératoire" and the chronology of the pictures. A topic which is directly linked but which has not yet been investigated concerns their renewal. Differences in the morphology of the engraved or pecked lines belonging to a same pattern can be seen as the result of distinct events. This has been the case with the bison of La Grèze cave, suspected to have been partly redrawn at the time of its discovery for making it more visible. A close examination of the outline with a binocular microscope and its 3D modeling at different scales show that, despite a fresh and white bottom of some parts of the groove, there is no evidence of secondary work : all the recent features are due to the natural alteration of the wall.

\section{INDEX}

Keywords: rock art, traceology, taphonomy, 3D

\section{AUTHOR}

\section{LYDIA ZOTKINA}

Institut d'Archéologie et d'ethnographie, branche sibérienne de l'Académie des Sciences de Russie, 17 perspective de l'Académicien Lavrentiev, 630090 Novosibirsk, Fédération de Russie et Université d'état de Novosibirsk, département d'archéologie et d'ethnographie, 2 rue Pirogova, 630090 Novosibirsk, Fédération de Russie - lidiazotkina@gmail.com 